\title{
Correlation between Perifollicular Vascularity and Outcome in Stimulated Intrauterine Insemination Treatment Cycles: A Study Using Two-Dimensional Transvaginal Power Doppler Ultrasound
}

\author{
Nadia M. Madkour, Wael S. Nossair*, Essa M. Arafa, Amany M. Abdelghany, \\ Ekramy A. Mohamed, Walid A. Abdelsalam \\ Obstetrics \& Gynecology Department, Faculty of Medicine, Zagazig University, Zagazig, Egypt \\ Email: wsnossair@gmail.com
}

Received 18 September 2014; revised 15 October 2014; accepted 6 November 2014

Copyright (C) 2014 by authors and Scientific Research Publishing Inc.

This work is licensed under the Creative Commons Attribution International License (CC BY). http://creativecommons.org/licenses/by/4.0/

(c) (i) Open Access

\section{Abstract}

Objective: The aim of this study is to assess any potential relationship between perifollicular vascularity and occurrence of pregnancy in cases of stimulated IUI cycles using the subjective grading system by 2D transvaginal power Doppler ultrasonography. Design: A prospective cross sectional cohort study. Method: This is a prospective cross-sectional cohort study of 90 stimulated IUI treatment cycles. Selected women were prescribed clomiphene citrate combined with highly purified urinary follicle stimulating hormone. All patients underwent serial transvaginal ultrasound scans starting from day 6 to 7 of the cycle. Perifollicular Doppler blood flows were assessed in dominant follicles $\geq 18 \mathrm{~mm}$. The patients then were categorized into 3 groups (high vascularity group \{G3 \& G4\}, low vascularity group \{G1 \& G2\} and mixed grades group). Other parameters measured included number of follicles $\geq 18 \mathrm{~mm}$ in both ovaries, endometrial thickness and estradiol $\left(E_{2}\right)$ level. Human chorionic gonadotropin (hCG) injection 10,000 IU IM was given to the patient when the dominant follicle reached $18 \mathrm{~mm}$ in diameter. At that time, the endometrium was evaluated as regards endometrial thickness. IUI was carried out using prepared/“washed" semen (husband). All patients received luteal support in the form of progesterone from day of IUI for 14 days. Serum B-hCG was estimated 2 weeks after insemination. Results: In this study, from all 90 cases only 8 cases got pregnant with pregnancy rate of $8.88 \%$ (6 cases got pregnant in high grade vascularity group; 2 cases in mixed grades group and no cases got pregnant in low grade group). There was statistically significant difference among the 3 groups as regarding the pregnancy rate $(P$ value $=$ 0.02). There is statistically significant difference in perifollicular resistance index (RI) and pulsa-

\footnotetext{
${ }^{*}$ Corresponding author.
} 
tility index (PI) between pregnant and non pregnant cases $(\mathrm{P}$ value $=0.016$ and 0.047 respectively). In this study, there is no statistically significant difference between pregnant and non pregnant cases as regarding endometrial thickness and $E_{2}$ level at the day of hCG administration (P value $=0.39$ and 0.76 respectively). Conclusion: Perifollicular blood-flow assessment by $2 \mathrm{D}$ transvaginal power Doppler is a good predictive for the outcome of stimulated IUI cycles.

\section{Keywords}

\section{Perifollicular Vascularity, IUI, 2D Power Doppler Ultrasound}

\section{Introduction}

Intrauterine insemination (IUI) has long been established as an alternative to other forms of assisted reproductive techniques (ART). The use of gonadotrophins in IUI has been shown to improve significantly the pregnancy rate. However, the risk of both ovarian hyperstimulation syndrome and multiple pregnancies is significantly increased. Despite this, IUI has cost savings and is less invasive compared with other forms of ART in particular for non-tubal infertility [1].

There are intense angiogenesis and increased capillary permeability during follicular development, ovulation and subsequent formation of the corpus luteum. Neovascularization is an important phenomenon for the growth and selection of ovulatory follicles as well as for the subsequent development and function of the corpus luteum. Studies of ovarian vasculature showed that the capillary network of preovulatory follicles was more extensive than that of other follicles. Therefore, initiation and maintenance of follicular growth depend on development of the follicular microvasculature [2].

The growing oocyte is provided with a developmental milieu like the intrafollicular level of oxygen and vascular endothelial growth factor (VEGF) that play a crucial role in the health of the developing oocyte. The vascularity of the parent follicle from which the oocyte is retrieved during IVF is known to influence the viability of the embryo [3].

With the development of power Doppler imaging, the pattern of perifollicular perfusion can be determined accurately. Transvaginal color flow Doppler has been used in several studies to assess uterine and ovarian blood flow patterns in ART cycles [4]-[7]. The blood flow in the wall of the preovulatory follicle can be used to assess the quality of the oocyte and to predict the potential success of ART cycles [4]. Greater blood flow in the wall of the preovulatory follicle has been associated with improved pregnancy rates of IUI [5] and in vitro fertilization (IVF) and embryo transfer [4]. Follicular blood-flow assessment by transvaginal color flow Doppler has been used during oocyte retrieval for selection of oocytes with better development as the vascularity tended to be greater for preovulatory follicles that contained a mature oocyte [7].

The aim of this study is to assess any potential relationship between perifollicular vascularity and occurrence of pregnancy in cases of stimulated IUI cycles using the subjective grading system by transvaginal Doppler ultrasonography.

\section{Patients and Method}

This is a prospective cross-sectional cohort study of 90 stimulated IUI treatment cycles carried out at Assisted Reproduction Unit in Zagazig University Hospital. This study was performed between January 2012 and January 2013.

Normogonadotropic women aged 20 - 38 years; with normal ovarian reserves, no previous surgeries on the ovary/ovaries, no tubal factor and of unexplained infertility were included in the study. We excluded women with endometriosis, polycystic ovarian disease, prior surgery, single ovary, severe male factor infertility and poor ovarian reserves.

The following was done for all selected patients: full history; full clinical examination; tubal patency test in the form of hysterosalpingogram or laparoscopy; semen analysis; and basal pelvic ultrasound scan to exclude pelvic pathology such as ovarian cysts before starting ovarian stimulation.

Women were prescribed clomiphene citrate (clomid tablets, 50 mg, Aventis Co., Cairo) administered orally, 
starting on the second day of the menstrual cycle for 5 consecutive days combined with highly purified urinary follicle stimulating hormone (fostimon vial, IBSA Co., Cairo) containing urofollitrophin 75 IU in the form of intramuscular injection.

All patients underwent serial transvaginal ultrasound scans starting from day 6 to 7 of the cycle and continued every alternate day until human chorionic gonadotropin (hCG) was administered using transvaginal ultrasound scan with power and color Doppler facilities (Medison Co. Accuvix V20, 7.5 MHz, South Korea). The size of the follicle was calculated by using the mean of two maximum diameters. Perifollicular Doppler blood flows were assessed in dominant follicles $\geq 18 \mathrm{~mm}$. We placed the power Doppler color over each ovarian follicle and then took a cross-sectional image of the follicle with the maximum color intensity representing the greatest Doppler frequency shifts. The follicular circumference was frozen and the perifollicular blood flow (PFBF) was graded based on Chui et al. [8]. According to this modified grading system, ovarian PFBF was represented as: Grade 0: 0\%, Grade 1: 1\% - 25\%, Grade 2: 26\% - 50\%, Grade 3: 51\% - 75\%, Grade 4: 76\% - 100\%. The flow velocity waveforms from the ovarian stromal or intra-ovarian arteries of both the ovaries were obtained in order to calculate the resistance index (RI), pulsatility index (PI) and systolic/diastolic ratio (S/D). A recording was considered satisfactory for measurement when there were three intense waveforms in a row and an average of each index in both ovaries was calculated. The patients then were categorized into 3 groups (high vascularity group $\{\mathrm{G} 3$ \& G4 $\}$, low vascularity group $\{\mathrm{G} 1 \& \mathrm{G} 2\}$ and Mixed grades group). Others parameters measured included number of follicles $\geq 18 \mathrm{~mm}$ in both ovaries, endometrial thickness and estradiol level. Human chorionic gonadotropin injection 10,000 IU IM (Pregnyl Ampoule 5000 IU, Nile Co., Cairo) was given to the patient when the dominant follicle reached $18 \mathrm{~mm}$ in diameter. At that time, the endometrium was evaluated as regards endometrial thickness. IUI was carried out using prepared/“washed” semen (husband). All patients received luteal support in the form of progesterone from day of IUI for 14 days. Serum B-hCG was estimated 2 weeks after insemination.

Statistical analysis was performed using STATA 11.0 (College Station, Texas, USA). Data were presented as a number (\%) or mean \pm standard deviation (SD)/median (range). The differences in Mean/Median values were measured by using Student's t-test (normal data distribution)/Wilcoxon Ranksum Test (for categorical variables). The correlation between outcome measures and perifollicular blood flow were calculated using Spearman rank correlation. $\mathrm{P}<0.05$ was considered to be statistically significant.

The study was approved by Zagazig University Medical Research Council Laboratories Joint Ethics Committee. All participants signed an informed consent. Rigorous confidentiality was maintained.

\section{Results}

Table 1 shows the demographic features of the studied patients. There is no statistically significant difference between the three groups as regarding age, body mass index (BMI) and type, duration and cause of infertility. There is no statistically significant difference in perifollicular PI and RI between the three groups $(\mathrm{P}$ value $=$ 0.83 and 0.32 respectively). There is no statistically significant difference between the three groups as regarding number of days from starting stimulation till day of HCG administration, diameter of follicles and endometrial thickness. There is no statistically significant difference between the three groups as regarding number of follicles and $\mathrm{E}_{2}$ level at the day of hCG administration ( $\mathrm{P}$ value $<0.0001$ and 0.018 respectively).

In this study, from all 90 cases only 8 cases got pregnant with pregnancy rate of $8.88 \%$ (6 cases got pregnant in high grade vascularity group; 2 cases in mixed grades group and no cases got pregnant in low grade group). There was statistically significant difference between the 3 groups as regarding the pregnancy rate $(\mathrm{P}$ value $=$ 0.02).There is statistically significant difference in perifollicular RI and PI between pregnant and non pregnant cases (P value $=0.016$ and 0.047 respectively). In this study, there is no statistically significant difference between pregnant and non pregnant cases as regarding endometrial thickness and $E_{2}$ level at the day of hCG administration ( $\mathrm{P}$ value $=0.39$ and 0.76 respectively) $($ Tables $2-4)$.

\section{Discussion}

A relationship between ovarian vascularity and chances of pregnancy has been reported since the early 1990s, but debate remains regarding the entity of this association and its clinical value [9]. In this study, from all 90 cases only 8 cases got pregnant with pregnancy rate $8.88 \%$ (6 cases got pregnant in high grade vascularity 
Table 1. Demographic data of the patients.

\begin{tabular}{|c|c|c|c|c|c|c|c|c|}
\hline & \multicolumn{2}{|c|}{ High grade } & \multicolumn{2}{|c|}{ Mixed grade } & \multicolumn{2}{|c|}{ Low grade } & $\mathrm{F}$ & $P$ value \\
\hline \multicolumn{9}{|l|}{ Age (year) } \\
\hline $\begin{array}{c}\text { Mean } \pm \text { SD } \\
\text { Range }\end{array}$ & \multicolumn{2}{|c|}{$\begin{array}{c}27.9 \pm 4.9 \\
21-38\end{array}$} & \multicolumn{2}{|c|}{$\begin{array}{c}28.5 \pm 4.1 \\
20-35\end{array}$} & \multicolumn{2}{|c|}{$\begin{array}{c}27.3 \pm 4.5 \\
20-35\end{array}$} & 0.62 & 0.53 \\
\hline $\begin{array}{c}\text { BMI } \\
\text { Mean } \pm \text { SD } \\
\text { Range }\end{array}$ & \multicolumn{2}{|c|}{$\begin{array}{c}26.7 \pm 2.1 \\
22.6-30\end{array}$} & \multicolumn{2}{|c|}{$\begin{array}{c}26.7 \pm 2.4 \\
23-30\end{array}$} & \multicolumn{2}{|c|}{$\begin{array}{c}26.6 \pm 2.2 \\
22-30\end{array}$} & 0.01 & 0.98 \\
\hline Type of infer & $\mathrm{n}$ & $\%$ & $\mathrm{n}$ & $\%$ & $\mathrm{n}$ & $\%$ & & \\
\hline Primary & 17 & 56.7 & 15 & 50 & 19 & 63.3 & 1.09 & 0.58 \\
\hline Secondary & 13 & 43.3 & 15 & 50 & 11 & 36.7 & & \\
\hline \multicolumn{9}{|l|}{ Duration of infer } \\
\hline $\begin{array}{c}\text { Mean } \pm \text { SD } \\
\text { Range }\end{array}$ & \multicolumn{2}{|c|}{$\begin{array}{c}3.4 \pm 2.1 \\
1-8\end{array}$} & \multicolumn{2}{|c|}{$\begin{array}{c}3.36 \pm 1.7 \\
1-8\end{array}$} & \multicolumn{2}{|c|}{$\begin{array}{c}3.7 \pm 2.2 \\
1-8\end{array}$} & 0.24 & 0.78 \\
\hline Cause of infer & $\mathrm{n}$ & $\%$ & $\mathrm{n}$ & $\%$ & $\mathrm{n}$ & $\%$ & & \\
\hline Unexplained & 15 & 50 & 15 & 50 & 15 & 50 & 0.22 & 0.99 \\
\hline Male factor & 5 & 16.7 & 4 & 13.3 & 4 & 13.3 & 0.22 & 0.99 \\
\hline Female factor & 10 & 33.3 & 11 & 36.7 & 11 & 36.7 & & \\
\hline
\end{tabular}

Table 2. Data on stimulation regime, ovarian and endocrine response of the patients.

\begin{tabular}{|c|c|c|c|c|c|}
\hline & High grade & Mixed grade & Low grade & $\mathrm{F}$ & $P$ value \\
\hline $\begin{array}{l}\text { No. of days from st } \\
\text { stimulation to HCC } \\
\text { ministration } \\
\text { Mean } \pm \text { SD } \\
\text { Range }\end{array}$ & $\begin{array}{c}13.5 \pm 1.7 \\
9-17\end{array}$ & $\begin{array}{c}13.6 \pm 1.4 \\
10-16\end{array}$ & $\begin{array}{c}14.16 \pm 1.97 \\
10-19\end{array}$ & 1.44 & 0.24 \\
\hline $\begin{array}{l}\text { No of follicles } \\
\text { Mean } \pm \text { SD } \\
\text { Range }\end{array}$ & $\begin{array}{c}1.3 \pm 0.7 \\
1-4\end{array}$ & $\begin{array}{c}2.2 \pm 0.4 \\
2-3\end{array}$ & $\begin{array}{c}1.53 \pm 0.7 \\
1-4\end{array}$ & 17.3 & $<0.0001^{*}$ \\
\hline $\begin{array}{c}\text { Diameter of follic } \\
\text { Mean } \pm \text { SD } \\
\text { Range }\end{array}$ & $\begin{array}{c}20.1 \pm 1.5 \\
18-23\end{array}$ & $\begin{array}{c}19.7 \pm 1.2 \\
18-23\end{array}$ & $\begin{array}{c}19.7 \pm 1.2 \\
18-23\end{array}$ & 0.62 & 0.53 \\
\hline $\begin{array}{c}\text { PI } \\
\text { Mean } \pm \text { SD } \\
\text { Range }\end{array}$ & $\begin{array}{l}0.9 \pm 0.08 \\
0.8-1.09\end{array}$ & $\begin{array}{c}0.91 \pm 0.08 \\
0.81-1.09\end{array}$ & $\begin{array}{c}0.9 \pm 0.07 \\
0.83-1.09\end{array}$ & 0.18 & 0.83 \\
\hline $\begin{array}{c}\text { RI } \\
\text { Mean } \pm \text { SD } \\
\text { Range }\end{array}$ & $\begin{array}{c}0.496 \pm 0.07 \\
0.43-0.67\end{array}$ & $\begin{array}{c}0.48 \pm 0.04 \\
0.43-0.58\end{array}$ & $\begin{array}{l}0.5 \pm 0.05 \\
0.43-0.6\end{array}$ & 1.13 & 0.32 \\
\hline $\begin{array}{c}\text { ET } \\
\text { Mean } \pm \text { SD } \\
\text { Range }\end{array}$ & $\begin{array}{c}9.2 \pm 1.26 \\
7.6-13\end{array}$ & $\begin{array}{c}9.76 \pm 1.1 \\
7.6-12\end{array}$ & $\begin{array}{c}9.5 \pm 1.3 \\
8-12\end{array}$ & 1.6 & 0.1 \\
\hline $\begin{array}{l}\text { E2 level } \\
\text { Mean } \pm \text { SD } \\
\text { range }\end{array}$ & $\begin{array}{c}521.8 \pm 106 \\
401-879\end{array}$ & $\begin{array}{c}607.1 \pm 106^{*} \\
490-927\end{array}$ & $\begin{array}{c}573 \pm 130.2 \\
412-987\end{array}$ & 4.18 & $0.018^{*}$ \\
\hline $\begin{array}{l}\text { Day of IUI } \\
\text { Mean } \pm \text { SD } \\
\text { Range }\end{array}$ & $\begin{array}{c}14.4 \pm 1.9 \\
11-18\end{array}$ & $\begin{array}{c}14.5 \pm 1.6 \\
12-17\end{array}$ & $\begin{array}{c}15.2 \pm 2.2 \\
11-20\end{array}$ & 0.74 & 0.48 \\
\hline
\end{tabular}

Table 3. Pregnancy rates among the studied groups.

\begin{tabular}{ccccccccc}
\hline & \multicolumn{2}{c}{ High grade } & \multicolumn{2}{c}{ Mixed grade } & Low grade & F & P value \\
\hline Pregnancy & $\mathrm{n}$ & $\%$ & $\mathrm{~N}$ & $\%$ & $\mathrm{~N}$ & $\%$ & $(7.68)^{*}$ & $(0.02)^{*}$ \\
Negative & 24 & 80 & 28 & 93.3 & $30^{*}$ & 100 & $(0)^{*}$ & $(0)$
\end{tabular}


Table 4. Data on patient characteristics, stimulation regime and ovarian and endocrine resonse of pregnant and non pregnant cases.

\begin{tabular}{|c|c|c|c|c|}
\hline & $\begin{array}{c}-\mathrm{VE} \\
\mathrm{n}=82\end{array}$ & $\begin{array}{l}+\mathrm{VE} \\
\mathrm{n}=8\end{array}$ & $\mathrm{~T}$ & $P$ value \\
\hline $\begin{array}{c}\text { Age (year) } \\
\text { Mean } \pm \text { SD } \\
\text { Range }\end{array}$ & $\begin{array}{c}28 \pm 4.6 \\
20-38\end{array}$ & $\begin{array}{c}26.8 \pm 3.7 \\
22-34\end{array}$ & 0.81 & 0.4 \\
\hline $\begin{array}{c}\text { BMI } \\
\text { Mean } \pm \text { SD } \\
\text { Range }\end{array}$ & $\begin{array}{c}26.7 \pm 2.2 \\
22-30\end{array}$ & $\begin{array}{c}27.1 \pm 2.3 \\
23.6-30\end{array}$ & 0.57 & 0.56 \\
\hline $\begin{array}{l}\text { Duration of infer } \\
\text { Mean } \pm \text { SD } \\
\text { Range }\end{array}$ & $\begin{array}{c}3.37 \pm 2 \\
1-8\end{array}$ & $\begin{array}{c}4.4 \pm 1.9 \\
2-7\end{array}$ & 1.5 & 0.13 \\
\hline $\begin{array}{l}\text { Cause of infer } \\
\text { Unexplained } \\
\text { Male factor } \\
\text { Female factor }\end{array}$ & $\begin{array}{c}\% \\
53.68 \\
12.32 \\
33.8\end{array}$ & $\begin{array}{c}\% \\
12.5 \\
25 \\
62.5\end{array}$ & 4.57 & 0.1 \\
\hline $\begin{array}{l}\text { Type of infertility } \\
\text { Primary } \\
\text { Secondary }\end{array}$ & $\begin{array}{c}\% \\
57.5 \\
42.5\end{array}$ & $\begin{array}{l}\% \\
50 \\
50\end{array}$ & 0.01 & 0.9 \\
\hline $\begin{array}{c}\text { No. of follicles } \\
\text { Mean } \pm \text { SD } \\
\text { Range }\end{array}$ & $\begin{array}{c}1.7 \pm 0.7 \\
1-4\end{array}$ & $\begin{array}{c}1.5 \pm 0.7 \\
1-3\end{array}$ & 0.9 & 0.36 \\
\hline $\begin{array}{l}\text { Diam. of follicles } \\
\text { Mean } \pm \text { SD } \\
\text { Range }\end{array}$ & $\begin{array}{c}19.7 \pm 1.3 \\
18-23\end{array}$ & $\begin{array}{c}20.3 \pm 1.3 \\
18-23\end{array}$ & 1.14 & 0.25 \\
\hline $\begin{array}{c}\text { PI } \\
\text { Mean } \pm \text { SD } \\
\text { Range }\end{array}$ & $\begin{array}{c}0.91 \pm 0.08 \\
0.8-1.09\end{array}$ & $\begin{array}{c}0.847 \pm 0.03 \\
0.8-0.9\end{array}$ & 2.43 & $0.016^{*}$ \\
\hline $\begin{array}{c}\text { RI } \\
\text { Mean } \pm \text { SD } \\
\text { Range }\end{array}$ & $\begin{array}{c}0.495 \pm 0.05 \\
0.43-0.67\end{array}$ & $\begin{array}{c}0.46 \pm 0.02 \\
0.43-0.5\end{array}$ & 2.01 & $0.047^{*}$ \\
\hline $\begin{array}{c}\text { ET } \\
\text { Mean } \pm \text { SD } \\
\text { Range }\end{array}$ & $\begin{array}{c}9.4 \pm 1.2 \\
7.6-13\end{array}$ & $\begin{array}{c}9.8 \pm 1.06 \\
8.9-12\end{array}$ & 0.85 & 0.39 \\
\hline $\begin{array}{c}\text { E2 level } \\
\text { Mean } \pm \text { SD } \\
\text { Range }\end{array}$ & $\begin{array}{c}568.7 \pm 121.3 \\
402-989\end{array}$ & $\begin{array}{c}556.4 \pm 102 \\
401-689\end{array}$ & 0.3 & 0.76 \\
\hline $\begin{array}{c}\text { IUI day } \\
\text { Mean } \pm \text { SD } \\
\text { Range }\end{array}$ & $\begin{array}{c}14.7 \pm 2 \\
11-20\end{array}$ & $\begin{array}{c}14.6 \pm 1.1 \\
13-16\end{array}$ & 0.12 & 0.9 \\
\hline
\end{tabular}

group; 2 cases in mixed grades group and no cases got pregnant in low grade group). There was statistically significant difference between the 3 groups as regarding the pregnancy rate ( $\mathrm{P}$ value $=0.02)$. There is statistically significant difference in perifollicular PI and RI between pregnant and non pregnant cases $(\mathrm{P}$ value $=0.016$ and 0.047 respectively). This trend towards better peri-follicular vascularity in women who got pregnant was demonstrated in previous studies [9]-[14]. In a study of 182 consecutive patients undergoing stimulated IUI cycles, the incidence of follicles showing high-grade peri-follicular vascularity was reported to be associated with better outcome [10]. Shrestha et al. demonstrated an upward trend in the proportion of large follicles with high-grade peri-follicular blood flow along the follicular phase in cycles resulting in pregnancy [11]. However, Chui etal. failed to demonstrate any significant difference in the intra-ovarian PI between those women who conceived and those who did not [7].

The mechanism underlying the link between follicular vascularity and implantation outcome remains unclear at present. However, possibilities include a link between ovarian follicular blood flow and oocyte quality. The quality and maturity of the oocyte depends on the intrafollicular levels of oxygen which in turn is directly proportional to the degree of follicular vascularity. Hence, PFBF may be used as a valid indirect marker of oocyte 
quality [12]. An association between poor follicular vascularity and aneuploidy has been observed by a number of authors [13] [14]. Chui et al. demonstrated that oocytes derived from follicles with low grade vascularity resulted in a significantly higher proportion of triploid embryos when compared to those derived from follicles with high grade vascularity [8]. Similarly, Bhal et al. showed a significantly higher oocyte retrieval rate, maturity and fertilization rate with significantly lower triploidy rate in the group with high grade vascularized follicles [15]. The compromised perifollicular microcirculation leads to hypoxia which probably causes an increased incidence of aneuploidal oocytes. However, the question remains unanswered whether the hCG trigger injection used to induce ovulation alters the pattern of PFBF by the time oocyte recovery is performed. It has been demonstrated that the exogenous hCG or endogenous luteinizing hormone surge increases angiogenesis of human ovarian follicles by increasing the local angiogenic factor VEGF production [14].

In this study, there is no statistically significant difference between pregnant and non pregnant cases as regarding endometrial thickness ( $\mathrm{P}$ value $=0.39$ ). Chien et al. studied the effect of endometrial thickness and pattern measured using ultrasound upon pregnancy outcomes in patients undergoing IVF-ET. They assessed and recorded endometrial patterns and thickness on the day of hCG administration. They concluded that endometrial thickness and pattern independently affect pregnant outcomes [16]. Combined endometrial thickness and pattern could not predict the outcome of IVF-ET when endometrial thickness was $<7 \mathrm{~mm}$ or $>14 \mathrm{~mm}$, while a triple-line pattern with a moderate endometrial thickness appeared to be associated with a good clinical outcome [17].

In this study, there is no statistically significant difference between pregnant and non pregnant cases as regarding $E_{2}$ level at the day of hCG administration ( $P$ value $=0.76$ ). High $E_{2}$ levels have been shown to affect embryonic adhesion, while a negative association between the probability of pregnancy and $E_{2}$ levels on the day of hCG has been reported [18]. On the other hand, several studies have suggested that pregnancy achievement is independent of $\mathrm{E}_{2}$ levels on the day of hCG administration [19].

An adequate blood supply remains fundamental in the regulation of intrafollicular oxygen levels and the determination of oocyte quality. We performed this study using 2D power Doppler which has its own limitations. The information regarding the vascularization and blood flow is derived from a single artery, which may not be the true representative of the surrounding vasculature or total ovarian blood flow [20]. Furthermore, the accuracy of measurement of blood flow velocity is dependent on the angle of insonation to the blood vessels. This may at times be difficult to measure correctly as the arteries within the ovary are not only small but tortuous also [21]. Our study was designed prospectively using 2D color and power Doppler technology. The door is open to larger studies using 3D Doppler technology to be performed in order to substantiate our results. Three dimensional power Doppler is essentially more sensitive, angle independent and evaluates the total vascularization and blood flow of the ovary [22].

\section{Conclusion}

Perifollicular blood-flow assessment by 2D transvaginal power Doppler ultrasonography is a good predictive for the outcome of stimulated IUI cycles.

\section{Acknowledgements}

The author would like to thank all patients included in the study. The author acknowledges the support of the all staff members of Obstetrics and Gynaecology department faculty of medicine Zagazig University for their support.

\section{Disclosure of Interests}

None.

\section{Funding}

All patient included in study at fund of Zagazig University Hospitals which under the funding of ministry of higher education in Egypt.

\section{References}

[1] Ragni, G., Anselmino, M., Nicolosi, A.E., Brambilla, M.E., Calanna, G. and Somigliana, E. (2007) Follicular Vascularity Is Not Predictive of Pregnancy Outcome in Mild Controlled Ovarian Stimulation and IUI Cycles. Human Re- 
production, 22, 210-214. http://dx.doi.org/10.1093/humrep/del362

[2] Du, B., Takahashi, K., Ishida, G.M., Nakahara, K., Saito, H. and Kurachi, H. (2006) Usefulness of Intraovarian Artery Pulsatility and Resistance Indices Measurement on the Day of Follicle Aspiration for the Assessment of Oocyte Quality. Fertility and Sterility, 85, 366-370. http://dx.doi.org/10.1016/j.fertnstert.2005.07.1316

[3] Coulam, C.B., Goodman, C. and Rinehart, J.S. (1999) Color Doppler Indices of Follicular Blood Flow as Prediction of Pregnancy after in-Vitro Fertilization and Embryo Transfer. Human Reproduction, 14, 1979-1982. http://dx.doi.org/10.1093/humrep/14.8.1979

[4] Steer, C.V., Campbell, S., Tan, S.L., Crayford, T., Mills, C., Mason, B.A. and Collins, W.P. (2003) The Use of Transvaginal Color Flow Imaging after in Vitro Fertilization to Identify Optimum Uterine Conditions before Embryo Transfer. Fertility and Sterility, 57, 372-376.

[5] Costello, M.F., Shrestha, S.M., Sjoblom, P., McNally, G., Bennett, M.J., Steigrad, S.J. and Hughes, G.J. (2006) Power Doppler Ultrasound Assessment of the Relationship between Age and Ovarian Perifollicular Blood Flow in Women Undergoing in Vitro Fertilization Treatment. Journal of Assisted Reproduction and Genetics, 23, 359-365. http://dx.doi.org/10.1007/s10815-006-9067-8

[6] Järvelä, I.Y., Sladkevicius, P., Kelly, S., Ojha, K., Nargund, G. and Campbell, S. (2002) Three-Dimensional Sonographic and Power Doppler Characterization of Ovaries in Late Follicular Phase. Ultrasound in Obstetrics \& Gynecology, 20, 281-285. http://dx.doi.org/10.1046/j.1469-0705.2002.00777.x

[7] Nargund, G., Bourne, T., Doyle, P., Parsons, J., Cheng, W., Campbell, S. and Collins, W. (1996) Associations between Ultrasound Indices of Follicular Blood Flow, Oocyte Recovery and Preimplantation Embryo Quality. Human Reproduction, 11, 109-113.

[8] Chui, D.K.C., Pugh, N.D., Walker, S.M., Gregory, L. and Shaw, R.W. (1997) Follicular Vascularity-The Predictive Value of Transvaginal Power Doppler Ultrasonography in an in-Vitro Fertilization Programme: A Preliminary Study. Human Reproduction, 12, 191-196. http://dx.doi.org/10.1093/humrep/12.1.191

[9] Zhang, Y., Yang, J. and Xu, W.M. (2008) Study on Relationship between Perifollicular Blood Flow and in Vitro Fertilization-Embryo Transfer. Journal of Nanjing Medical University, 22, 57-60.

[10] Oyesanya, O.A., Parsons, J.H., Collins, W.P., et al. (1996) Prediction of Oocyte Recovery Rate by Transvaginal Ultrasonography and Color Doppler Imaging before Human Chorionic Gonadotropin Administration in in Vitro Fertilization Cycles. Fertility and Sterility, 65, 806-809.

[11] Shrestha, S.M., Costello, M.F., Sjoblom, P., McNally, G., Bennett, M., Steigrad, S.J. and Hughes, G.J. (2006) Power Doppler Ultrasound Assessment of Follicular Vascularity in the Early Follicular Phase and Its Relationship with Outcome of in Vitro Fertilization. Journal of Assisted Reproduction and Genetics, 23, 161-169. http://dx.doi.org/10.1007/s10815-006-9029-1

[12] Malhotra, N., Bahadur, A., Singh, N., Kalaivani, M. and Mittal, S. (2014) Role of Perifollicular Doppler Blood Flow in Predicting Cycle Response in Infertile Women with Genital Tuberculosis Undergoing in Vitro Fertilization/Intra Cytoplasmic Sperm Injection. Journal of Human Reproductive Sciences, 7, 19-24. http://dx.doi.org/10.4103/0974-1208.130809

[13] Van Blerkom, J. (1996) The Influence of Intrinsic and Extrinsic Factors on the Developmental Potential and Chromosomal Normality of the Human Oocyte. Journal of the Society for Gynecologic Investigation, 3, 3-11. http://dx.doi.org/10.1016/1071-5576(95)00041-0

[14] Van Blerkom, J., Antczak, M. and Schrader, R. (1997) The Developmental Potential of the Human Oocyte Is Related to the Dissolved Oxygen Content of Follicular Fluid: Association with Vascular Endothelial Growth Factor Levels and Perifollicular Blood Flow Characteristics. Human Reproduction, 12, 1047-1055. http://dx.doi.org/10.1093/humrep/12.5.1047

[15] Bhal, P.S., Pugh, N.D., Chui, D.K., Gregory, L., Walker, S.M. and Shaw, R.W. (1999) The Use of Transvaginal Power Doppler Ultrasonography to Evaluate the Relationship between Perifollicular Vascularity and Outcome in in-Vitro Fertilization Treatment Cycles. Human Reproduction, 14, 939-945. http://dx.doi.org/10.1093/humrep/14.4.939

[16] Chien, L.W., Au, H.K., Chen, P.L. and Tzeng, C.R. (2002) Assessment of Uterine Receptivity by the EndometrialSubendometrial Blood Flow Distribution Pattern in Women Undergoing in-Vitro Fertilization Embryo Transfer. Fertility and Sterility, 78, 245-251. http://dx.doi.org/10.1016/S0015-0282(02)03223-5

[17] Chen, S.-L., Wu, F.-R., Luo, C., Chen, X., Shi, X.-Y., Zheng, H.-Y. and Ni, Y.-P. (2010) Combined Analysis of Endometrial Thickness and Pattern in Predicting Outcome of in Vitro Fertilization and Embryo Transfer: A Retrospective Cohort Study. Reproductive Biology and Endocrinology, 8, 30. http://www.rbej.com/content/8/1/30 http://dx.doi.org/10.1186/1477-7827-8-30

[18] Chenette, P.E., Sauer, M.V. and Paulson, R.J. (1990) Very High Serum E2 Levels Are Not Detrimental to Clinical Outcome of in Vitro Fertilization. Fertility and Sterility, 54, 858-863. 
[19] Kosmas, I.P., Kolibianakis, E.M. and Devroey, P. (2004) Association of Estradiol Levels on the Day of hCG Administration and Pregnancy Achievement in IVF: A Systematic Review. Human Reproduction, 19, 2446-2453. http://dx.doi.org/10.1093/humrep/deh473

[20] Lozano, D.H.M., et al. (2007) The 3D Vascular Status of the Follicle after hCG Administration Is Qualitatively Rather than Quantitatively Associated with Its Reproductive Competence. Human Reproduction, 22, 1095-1099. http://dx.doi.org/10.1093/humrep/del472

[21] Ng, E.H., Chan, C.C., Tang, O.S., Yeung, W.S. and Ho, P.C. (2006) The Role of Endometrial and Subendometrial Blood Flows Measured by Three-Dimensional Power Doppler Ultrasound in the Prediction of Pregnancy during IVF Treatment. Human Reproduction, 21, 164-170. http://dx.doi.org/10.1093/humrep/dei277

[22] Kupesic, S., Kurjak, A., Bjelos, D. and Vujisic, S. (2003) Three-Dimensional Ultrasonographic Ovarian Measurements and in Vitro Fertilization Outcome Are Related to Age. Fertility and Sterility, 79, 190-197. http://dx.doi.org/10.1016/S0015-0282(02)04567-3 
Scientific Research Publishing (SCIRP) is one of the largest Open Access journal publishers. It is currently publishing more than 200 open access, online, peer-reviewed journals covering a wide range of academic disciplines. SCIRP serves the worldwide academic communities and contributes to the progress and application of science with its publication.

Other selected journals from SCIRP are listed as below. Submit your manuscript to us via either submit@scirp.org or Online Submission Portal.
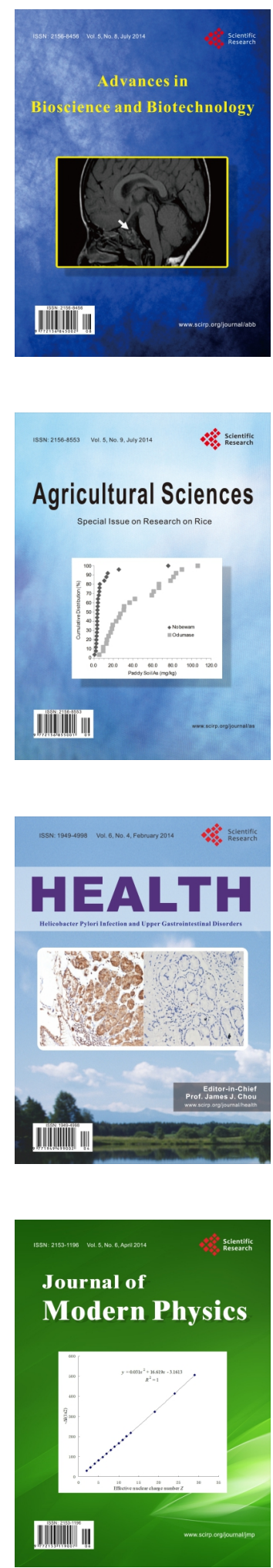
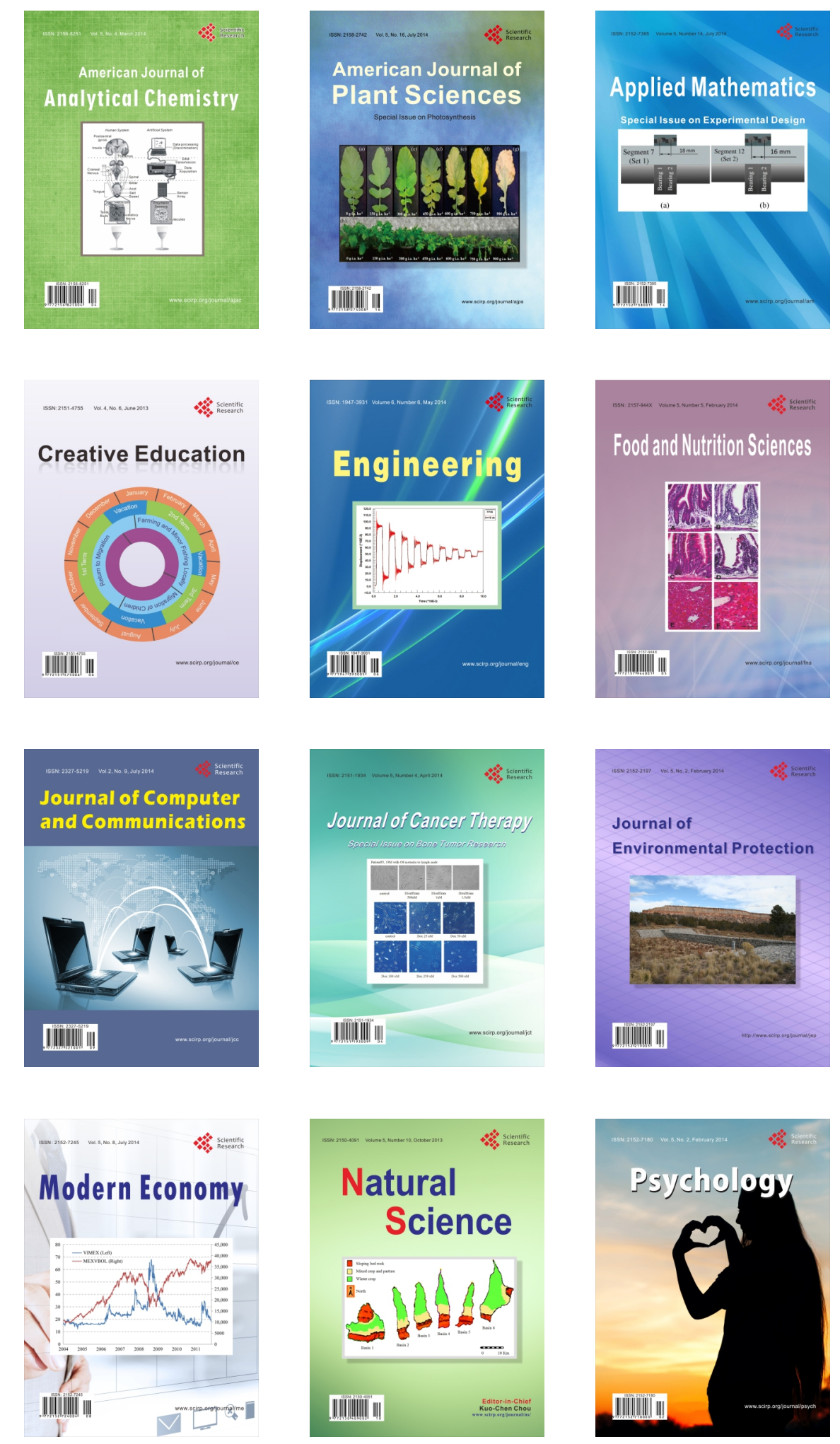